\title{
Historical perspectives of The American Association for Thoracic Surgery: Robert B. Wallace
}

\author{
John V. Conte, MD
}

Robert Bruce Wallace, the 75th president of The American Association for Thoracic Surgery (AATS), was born in Washington, DC, on April 12, 1931. He was the second of 3 sons of William B. Wallace and Ann Silver Wallace. Robert was the only one of his siblings who chose a career in medicine; the others worked in the insurance industry. He initially attended public school as a youth but received a scholarship to attend St Peter's School in Peekskill, New York, for high school.

\section{EDUCATION AND EARLY LIFE}

Wallace was an outstanding football and baseball player at St Peter's, and at the time of his graduation, he had to choose between a scholarship to attend Columbia University to play football or a professional minor league baseball contract. ${ }^{1}$ Ultimately, he decided to go to Columbia where he would join his older brother on the football team and play under legendary coach Lou Little, whom he has credited with being one of his most influential mentors. At Columbia, Robert was a 2-sport standout, and as he approached graduation, he again faced a difficult career choice. With the encouragement of Coach Little and others, he applied to only one medical school and was accepted at the Columbia University College of Physicians and Surgeons in 1953.

\section{MEDICAL EDUCATION AND SURGICAL TRAINING}

Wallace planned to pursue a career in internal medicine and early in his fourth year of medical school had applied for medical internships. However, this all changed during his first surgical clerkship in his final year under the influence of chief residents Keith Reemsma (71st AATS president) and James Malm (66th AATS president). These future cardiac surgery leaders influenced Wallace to pursue a surgical residency, which he initiated at St Vincent's Hospital in New York under Dr David Rousellot from 1957 to 1962. Dr George Morris was a visiting professor from Baylor University at the time and convinced Dr Wallace to move

\footnotetext{
From the Division of Cardiac Surgery, Department of Surgery, Johns Hopkins Medical Institutions, Baltimore, Md.

Disclosures: Author has nothing to disclose with regard to commercial support.

Received for publication Nov 17, 2013; accepted for publication Dec 23, 2013; available ahead of print Feb 9, 2014.

Address for reprints: John V. Conte, MD, Division of Cardiac Surgery, Department of Surgery, Johns Hopkins Medical Institutions, 600 N. Wolfe St, Blalock 618, Baltimore, MD 21287 (E-mail: jconte@jhmi.edu).

J Thorac Cardiovasc Surg 2014;148:2-4

0022-5223/\$36.00

Copyright (c) 2014 by The American Association for Thoracic Surgery

http://dx.doi.org/10.1016/j.jtcvs.2013.12.030
}

on to Methodist Hospital in Houston because of the exciting advances in the field of vascular surgery that were occurring. Dr Wallace trained under Dr Stanley Crawford and Dr Denton Cooley from 1962 to 1963 , both of whom were not only mentors but also lifelong friends and colleagues. He also appreciated the exacting lessons provided by Dr Michael DeBakey (38th AATS president), who had a profound influence on his professional development. Wallace originally intended to return to St Vincent's to practice, but he was encouraged by Dr John Kirklin (59th AATS president) to come to the Mayo Clinic for a fellowship in the nascent field of cardiac surgery from 1963 to 1964.

\section{THE MAYO YEARS}

Dr Kirklin invited Wallace to join the faculty at Mayo after his fellowship to become the fourth cardiac surgeon with Kirklin, Dwight McGoon (64th AATS president), and Gordon Danielson. Wallace thrived in Rochester, making significant contributions in the fields of both congenital and acquired cardiovascular diseases. He developed a reputation as an excellent technical surgeon, teacher, and role model for his colleagues and trainees. Dr Robert Frye, a cardiology colleague at Mayo, remembered Wallace above all as a "gentleman who exuded professionalism and quiet confidence" (personal communication, June 15, 2012). One of his most noteworthy accomplishments was the performance of the first Rastelli operation for transposition of the great vessels on July 26,1968 . Wallace recounts this time as one of the exciting developments in cardiac surgery and his most productive period academically. His most satisfying aspect of the Mayo years was the development of an American Board of Surgeryapproved training program in surgery and American Board of Thoracic Surgery-approved training program in thoracic surgery to supplant the fellowship programs that exclusively existed at the Mayo Clinic up to that point.

\section{THE GEORGETOWN YEARS}

Georgetown University had a strong history in cardiology and cardiac surgery in the 1950s and 1960s that was led by doctors Proctor Harvey and Charles Hufnagel. By the end of the 1970s, their position of leadership had waned. When the opportunity to meet a new challenge and return to his hometown arose, Wallace made the move to Georgetown. As reflected in an article in the Georgetown Medical Bulletin in 1980, Wallace's plan was to develop a strong academic surgery program in the nation's capital and continue his clinical pursuits. " "I strongly believe that one cannot head a department of surgery without being a clinical 
surgeon...It would seem important that Washington DC have a strong university-based cardiac program."

In recent years, Wallace has reflected on the impact that some of the "cardiac surgery giants," such as Cooley, DeBakey, Crawford, and Kirklin, had on his career. Wallace's own career reflects the importance of mentorship and being a role model for surgical trainees. Stephen R. T. Evans, a surgical oncologist, who served as the Chairman of the Georgetown Department of Surgery, remembers Wallace as "the boss" who was "dedicated to his patients and his trainees" (personal communication, August 16, 2012). Dr Philip Corcoran remembers Wallace as "a technical maestro" (personal communication, November 14, 2011), and Dr Joseph Dearani remembers him as "the single most important surgical role model I had and the one whom I have tried to emulate the most in my career" (personal communication, September 12, 2011). These trainees and others, who have gone on to successful careers in thoracic, general, and vascular surgery, began the Robert Wallace Surgical Society in 1991.

Wallace was a fair, but demanding, leader who ran a tight ship. He was known among his trainees as one who valued neatness both in and out of the operating room. He had a strong sense of propriety and prohibited students, residents, and faculty from wearing surgical scrubs outside of the operating room. Dr Wallace sat in seat number 1 in the first row of the auditorium each Saturday for Grand Rounds, and with his eye on the clock would make note of those who arrived at 8:01 AM. Absences required a written explanation the following Monday, and on one notable occasion, the letter came hand-delivered with a picture of the proud resident's newborn baby. The resident noted that his wife delivered his first child at the same time grand rounds were being held. Without missing a beat Wallace replied, "That explains why SHE wasn't there" (Russell C. Nauta, MD, personal communication, September 30, 2011).

Wallace was also a man of notable humility who did not seek notoriety for his many accomplishments. He introduced

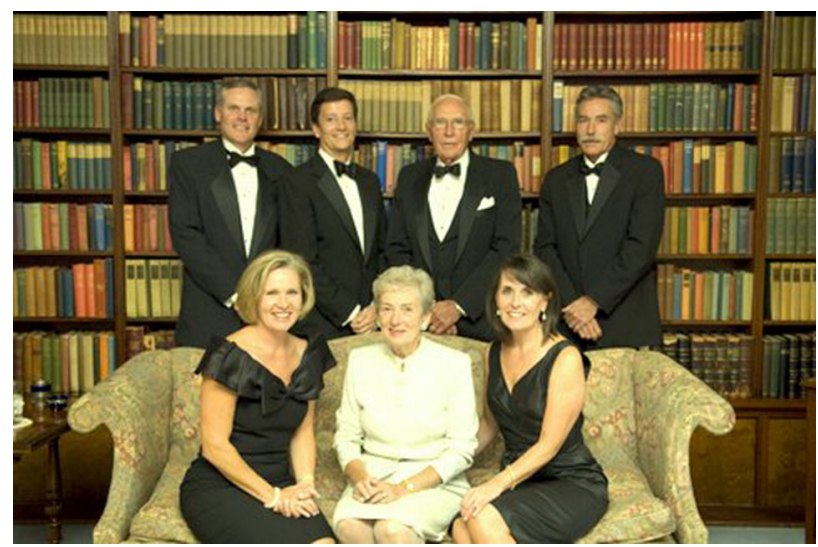

FIGURE 1. Dr Robert Bruce Wallace and wife Betty Wallace and family at his Distinguished Alumni Award Reception, Rochester, Minnesota, 2008. himself to patients simply as "one of the surgeons here at Georgetown." Russ Nauta, who directed the Division of General Surgery at Georgetown, recounted a story that reflected Dr Wallace's down to earth nature and sense of humor. As Wallace's guest at an American Surgical Association meeting, the 2 sat together while a large series of patients with near perfect results were being presented proudly by a man with whom Dr Wallace had trained. Wallace leaned over to Nauta during the presentation and explained, "He did quite a few cases before he started counting...." (Russell C. Nauta, MD, personal communication, September 30, 2011).

Dr Wallace married his high school sweetheart Betty Newell in 1956, and they had 3 children. They currently live in retirement in McLean, Virginia, and travel frequently to spend time with their children and grandchildren. Dr Wallace has been an avid sportsman throughout his life, enjoying hunting and fishing, as well as competitive tennis and golf. Since retirement, Dr Wallace has spent time with his family and remained active in the AATS and American College of Surgeons, and as head of the Scientific Advisory Committee of the LeDucq Foundation, a private foundation involved in cardiovascular research. In 2008, Dr Wallace was honored by the Mayo Clinic with the Distinguished Alumni Award for his lifelong contributions in the treatment of cardiovascular disease (Figure 1).

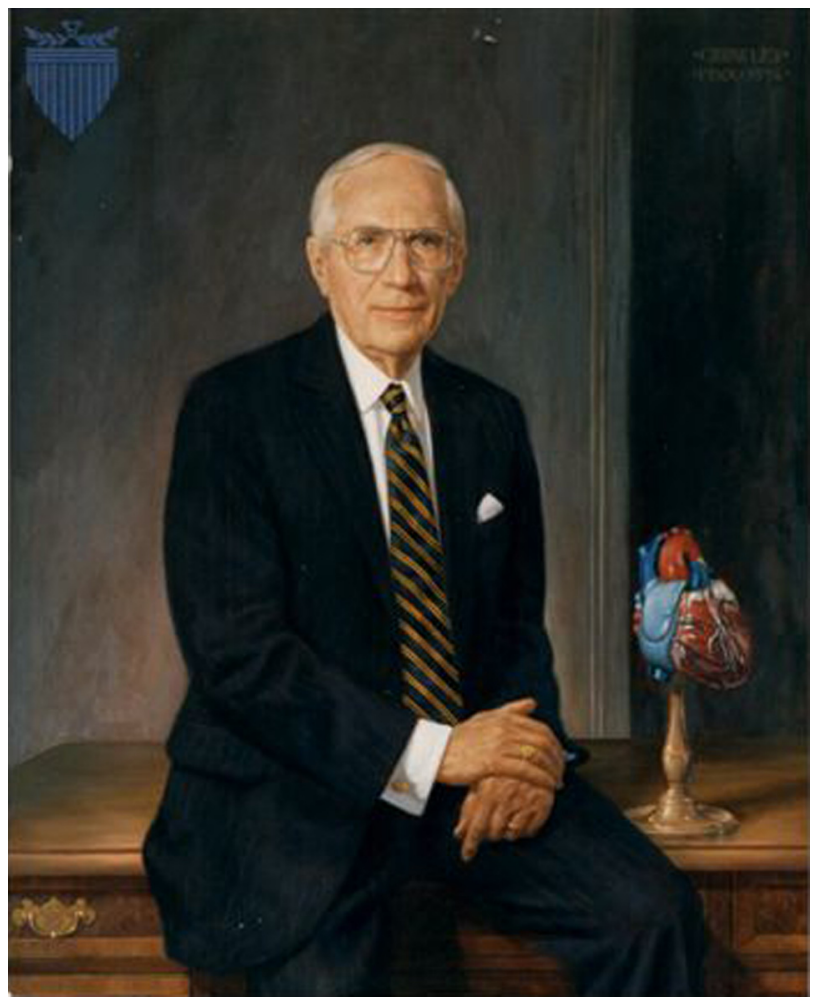

FIGURE 2. Painting of Dr Robert Bruce Wallace that hangs at the Mayo Clinic. 


\section{CONCLUSIONS}

As a Wallace trainee myself, I have been most impressed over the years with his "common sense" and my impression that he definitely "got it," both in surgery and in life. Dr Wallace supported the academic efforts of all his residents and gave us many opportunities to mingle with the world's leaders in cardiac surgery as part of our professional development. I will never forget a dinner hosted by Dr Wallace at the AATS meeting in Washington, DC, when I was a thirdyear general surgery resident. I listened in awe as Dr Christian Cabrol and Dr David Sabiston (65th AATS president) sat with me and my date during dinner and made us feel as though we were the 2 most important people at the table that night. Most important, Dr Wallace once shared with me his secret to a successful academic career in cardiac surgery. "Pick the right wife," he said, "I could have never done it without Betty," which is sage advice I followed as I have tried to emulate his attributes in my own career and personal life (Figure 2).

\section{References}

1. Stoney WS. Pioneers of Cardiac Surgery. Nashville, TN: Vanderbilt University Press; 2008.

2. Lee TE. The Georgetown Medical Bulletin. 1980;XXXIII:1-4. 